\title{
Conservation Status of Fish Fauna in the Ivo River Basin Southeast, Nigeria
}

\section{ASIEGBU Victoria Onyebuchi ${ }^{1}$, OYEDIRAN Ajiboye Gabriel $^{2}$ and EZEKWE Ifeanyichukwu Clinton ${ }^{1,3 *}$}

${ }^{1}$ Department of Geography and Environmental Management, University of Port Harcourt, Nigeria

${ }^{2}$ Department of Fisheries Technology, Federal College of Agriculture, Ishiagu. Ebonyi State, Nigeria

${ }^{3}$ National Weather Forecasting and Climate Research Centre, Abuja

*Corresponding Author: EZEKWE Ifeanyichukwu Clinton, Department of Geography and Environmental Management, University of Port Harcourt, Nigeria and National Weather Forecasting and Climate Research Centre, Abuja.
Received: November 27, 2020

Published: June 04, 2021

(C) All rights are reserved by EZEKWE

Ifeanyichukwu Clinton., et al.

\begin{abstract}
Ivo River Basin extends from the Aku stream, Abia State to Ivo River, Okpanku, Enugu State, Nigeria. It is exposed to several anthropogenic activities including aggregate and lead-zinc mining. These predisposes the aquatic environment and its fish fauna to management challenges. It is therefore important to investigate the conservation status of its fish fauna. Fish samples were collected from ten using purposefully selected sample sites using the gillnet and identification were done using standard guides. Fish trophic groups and conservation status were categorized according to International Union of Conservation of Nature (IUCN). Species diversity was determined with Shannon-Wiener's index. Five fish families comprising seven fish species were encountered with highest abundance of 32 individuals in the Ivo Dam and none in Ikwo and Ehu streams. Highest Shannon-Weiner diversity of 1.60 was recorded in the Aku stream. Schilbe intermedius was the most abundant species particularly in the Ivo Dam. The only forager found in the aquatic system was the Oreochromis niloticus while the other six species were carnivores. Anaspodeglanis akiri and Neolabias powelli were also found and has been categorized as endangered and critically endangered species respectively. The low fish abundance, diversity and the dominance of carnivorous species over foragers as well as the presence of endangered species and critically endangered species are indicative that the fish feeding relationship was not in balance signifying a river basin experiencing ecological disturbance with a poor conservation status for foragers. Therefore, a sustainable management strategy urgently needs to be put in place to restore an equilibrium of fish population in the river basin.
\end{abstract}

Keywords: Conservation Status; Ecological Disturbance; Endangered Species; Fish-feeding Relationship; Fish Population

\section{Introduction}

Fish is one the cheapest sources of animal protein to inhabitants of riverine communities of the world [1,2]. The sustainable exploitation of fish increase the economy gains of the fisher folks in these communities with a reciprocal good livelihood (Izah., et al. 2018). The conservation status of fish fauna is embodied in their abundance, distribution and diversity and this is continually perturbed by both intrinsic and extrinsic factors [3]. The extrinsic factors are worsened by climate change and different anthropogenic activities which could be within or from distant sources [4,5]. In the same vein, the increase in human population with its attendant fish demand has also posed a continuous pressure on fish population through overfishing along with obnoxious fishing methods that are adopted especially in the developing countries like Nigeria [6-8].
Intrinsic factors directly affect fish population through the feeding relationship of various fish groups. These play important roles in the different trophic levels for the maintenance of a balanced fish population and equilibrium environment [9]. Feeding relationship regulates fish population dynamics as fish food fluctuates on seasonal basis. Physical and chemical properties of the water especially temperature affects food consumption and the presence of food organisms especially planktons [10].

Ivo River Basin is a sub basin of Cross River Basin [11] with recharging water networks from Aku stream in Abia State, Ngada Headstream, Ikwo and Ivo Rivers all in Ebonyi State and Ehu system from Enugu State. The river basin is constantly exposed to pollution stress from aggregate mining discharges [12], lead and zinc mine 
wastes [13], fertilizer [14], pesticide and feacal wastes [15]. The effects of these pollutants are highly suspected to affect the fish fauna and may jeopardize their conservation status. The impacts of human perturbation in a water body might be more directed at a particular trophic level and the resultant low abundance in these groups creates an imbalance in the less affected trophic levels. There are no aggressive measures for enlightenment, regulations and monitoring against the various adverse impacts of different anthropogenic activities in and around water bodies in Nigeria [16]. The knowledge of the fish diversity viz a viz their feeding relationships which can be broadly categorized as forager and carnivore and their respective conservation status will aid strategic policies and planning for a sustainable management of the fish stocks and the study will be a baseline tool for similar research in future. It is therefore vital to investigate the fish abundance and diversity in Ivo River Basin with emphasis on feeding groups and their respective conservation status.

\section{Materials and Methods}

Ivo River Basin is located in Southeast, Nigeria. It is a sub-basin of the Cross River Basin, Nigeria [11]. The climate of the study area is tropical with mean daily temperature of $30 \pm 5^{\circ} \mathrm{C}$ for most period of the year. The annual rainfall is between 1900 and $2200 \mathrm{~mm}$, with wet and dry seasons. The vegetation is typically rainforest except in Ishiagu were it is derived savannah (Afiukwa., et al. 2019). The sampling was done in March 2019 in 10 stations for the purpose of the study. The stations are listed below \{Figure 1\}:

- Station 1: Aku River

- Station 2: Aku River at Afikpo

- Station 3: Ivo River joining Aku River

- Station 4: Ivo River at FCA Ishiagu

- Station 5: Ngada head stream

- Station 6: Ivo River at Okue Bridge

- Station 7: Ivo Dam at Mpu

- Station 8: Stream behind Sen. Ekweremadu

- Station 9: Ivo River at Okpanku

- Station 10: Ikwo River at Amagu.

Fish samples were caught using the 1.5"gillnet while fish identification was done using the key guides of Olaosebikan and Raji (2013) and Fishbase (2019). Fish abundance were categorized as least concerned, critically endangered and endangered while there feeding habits were grouped as forager and carnivore. Species diversity was determined with Shannon-Wiener's index using Palaeontological statistical software package (PAST 3) while Microsoft Excel 2013 was used for graphical representations.

\section{Results and Discussion}

There were five families of fish caught in the river basin (see Table 1) with a record of a species each for the respective fami- lies except for three carnivorous species for claroteidae including Anaspodeglanis akiri that is categorized as an endangered species as shown in table 2. Similarly, Neolabias powelli a Distichodontidae was reported as a critically endangered species by International Union of Conservation of Nature (IUCN) while the other species were of least concern. The critically endangered and endangered species were recorded in Aku Stream around the Mile 2 area of Ishiagu and at the Aku/Ivo River confluence \{Stations 2 and 3 respectively\}. The two stations were upstream of the river basin and are less perturbed as documented in previous work [13,15]. The carnivores were five while there was only one forager, the Nile tilapia Oreochromis niloticus in the river basin.

The dominance of carnivorous species in the river basin signifies an imbalanced feeding relationship, which deviates from the expected higher forager/carnivore ratio $[2,17]$ and the assumption that more abundance of cichlidae are in tropical waters $[18,19]$. The low abundance of this family in the water could be attributed to a stressed environment as overfishing is unlikely in this mostly farming community [20]. The cichlidae groups were probably more sensitive to the suspected poor water quality in the river basin as documented by earlier works. The low abundance of foragers in the river basin could be attributed to low availability of their food major sources of food which are majorly phytoplankton. Asiegbu., et al. [15] earlier reported a deteriorating water quality in the basin which affected abundance of plankton. Fish diet has been found to be an important factor governing fish growth, condition factor, fecundity and migration patterns [18]. This low forager to carnivore ratio is an impeding challenge to the sustainability of the fish fauna in the water body.

There were 10 species of fish encountered in the Ivo River Basin as shown in figure 1 . This is similar to the account of nine species in the wet season by Asiegbu., et al. [15] in the same study area. However, the higher species number recorded in the present study could be attributed to dry season period which is associated with water reduction, this resulted in low water volume for easier fish catch. Comparatively, the number in this study was below 15 and 69 unlike what was reported in Ikwori Lake by Offem., et al. [21] and Okogwu and Ugwumba [22] in the Mid Cross River which are water bodies in the lower part of the Cross River Basin respectively. The attenuated number of species in the Ivo River Basin could be attributed to the already reported cases of pollutions in the area $[13,14]$.

The high abundance of the African butter fish Shilbe intermedius depicted the possible presence of desired food and other enabling factors for the species. S. intermedius subsist mostly on insects [23] and aquatic insects strive more in an impoundment [24]. The surviving strength of this dominating species could also be related to its predatory nature (Abdul., et al. 2016). The high presence of this species could as well be connected with their adaptive nature to the suspected pollution stress which is contrary to the possible 
weak adaption of other groups which include Pelmatolapia mariae, Anaspidoglanis akiri and Auchenoglanis bisculatus.

There were more fish abundance in the Ivo Dam (station 7) compared to the total absence of fish in the Ehu system at Mpu (Station 8) and Ikwo River (Station 10) as shown in Table 3. Ivo Dam is the only lentic aspect of the river basin which was formed by the impoundment of the River at Mpu for water supply and hydroelectric purposes. Impoundments support more resident species than rheophilics and long distance migratory species because of their relative stable physical-chemical parameters compare to lotic waters which are exposed to regular changes occasioned by the water flow [25]. However, a low diversity index of 0.13 was recorded in Ivo Dam contrary to the high number of individuals caught, the low diversity index in this station was indicative that the species in the river basin were more tolerant to riverine condi- tions than a lacustrine nature of the dam. The high diversity index of 1.60 in Aku stream (Station 1) was not surprising, there were no previous records of obnoxious anthropogenic activities around the area compared to the records of several external pollution stress that have been established by various authors in other stations of the study area [13-15].

The hydrology of the area is a factor that possibly favored Aku stream (Station 1) as it is upstream and far from pollution sources in the downstream segments of the basin. The absence of fish in the Ehu system (Station 8) and Ikwo River (Station 10) were probably due to their seasonal nature, which disconnects the rivers from other water body and also hinders the movement of fish while the dry season period also leads to low water volumes which predisposes the endemic species to dangers of being overfished by the locals $[26,27]$.

\begin{tabular}{|c|c|c|c|c|c|c|c|c|c|c|c|c|}
\hline Family & Species & 1 & 2 & 3 & 4 & 5 & 6 & 7 & 8 & 9 & 10 & \\
\hline \multirow[t]{3}{*}{ Cichlidae } & & & & & & & & & & & & Total \\
\hline & $\begin{array}{c}\text { Oreochromis niloticus } \\
\text { Nile tilapia }\end{array}$ & 1 & 0 & 1 & 0 & 0 & 0 & 0 & 0 & 0 & 0 & 2 \\
\hline & $\begin{array}{l}\text { Pelmatolapia mariae } \\
\text { Spotted tilapia }\end{array}$ & 0 & 1 & 0 & 0 & 0 & 0 & 0 & 0 & 0 & 0 & 1 \\
\hline \multicolumn{13}{|c|}{ Claroteidae } \\
\hline & $\begin{array}{l}\text { Anaspidoglanis akiri } \\
\text { Ikorikori }\end{array}$ & 0 & 0 & 1 & 0 & 0 & 0 & 0 & 0 & 0 & 0 & 1 \\
\hline & $\begin{array}{c}\text { Auchenoglanis bisculatus } \\
\text { Koi }\end{array}$ & 0 & 0 & 0 & 0 & 1 & 0 & 0 & 0 & 0 & 0 & 1 \\
\hline & $\begin{array}{c}\text { Chrysichthys nigrodigitatus } \\
\text { Silver catfish }\end{array}$ & 1 & 0 & 1 & 0 & 1 & 0 & 0 & 0 & 0 & 0 & 3 \\
\hline & $\begin{array}{l}\text { Chrysichthys filamentous } \\
\text { Silver catfish }\end{array}$ & 0 & 0 & 0 & 0 & 0 & 1 & 0 & 0 & 0 & 0 & 1 \\
\hline \multicolumn{13}{|l|}{ Alestidae } \\
\hline & $\begin{array}{c}\text { Micralestes elongatus } \\
\text { Elongated turkana robbber }\end{array}$ & 1 & 0 & 0 & 2 & 1 & 2 & 1 & 0 & 0 & 0 & 7 \\
\hline \multicolumn{13}{|l|}{ Clariidae } \\
\hline & $\begin{array}{c}\text { Clarias gariepinus } \\
\text { Mud catfish }\end{array}$ & 1 & 1 & 2 & 0 & 0 & 0 & 0 & 0 & 0 & 0 & 4 \\
\hline \multicolumn{13}{|l|}{ Shilbeidae } \\
\hline & $\begin{array}{c}\text { Schilbe intermedius } \\
\text { Butter fish }\end{array}$ & 1 & 0 & 0 & 1 & 5 & 6 & 31 & 0 & 3 & 0 & 47 \\
\hline \multicolumn{13}{|c|}{ Distichodontidae } \\
\hline & Neolebias powelli & 0 & 1 & 0 & 0 & 0 & 0 & 0 & 0 & 0 & 0 & 1 \\
\hline & GRAND TOTAL & 5 & 3 & 5 & 3 & 8 & 9 & 32 & 0 & 3 & 0 & 68 \\
\hline
\end{tabular}

Table 1: Spatial fish abundance in Ivo River Basin. 


\begin{tabular}{|l|c|c|c|c|}
\hline Family & Specie & No & Trophic group & Conservation status \\
\hline Claroteidae & Chrysichthys nigridigitatus & 4 & Carnivore & Least concern \\
\hline & Anaspodeglanis akiri & 1 & Carnivore & Endangered \\
\hline & Auchenoglanis bisculatus & 1 & Carnivore & Least concern \\
\hline Clariidae & Clarias gariepinus & 3 & Carnivore & Least concern \\
\hline Schilbeidae & Schilbe intermedius & 3 & Carnivore & Least concern \\
\hline Cichlidae & Oreochromis niloticus & 2 & Forager & Least concern \\
\hline Distichodontidae & Neolabias powelli & 1 & Carnivore & Critically endangered \\
\hline
\end{tabular}

Table 2: Conservation Status of Fish Species in Ivo River Basin.

\begin{tabular}{|l|c|c|c|c|c|c|c|c|c|c|}
\hline Station & $\mathbf{1}$ & $\mathbf{2}$ & $\mathbf{3}$ & $\mathbf{4}$ & $\mathbf{5}$ & $\mathbf{6}$ & $\mathbf{7}$ & $\mathbf{8}$ & $\mathbf{9}$ & $\mathbf{1 0}$ \\
\hline Abundance & 5 & 3 & 5 & 3 & 8 & 9 & 32 & 0 & 3 & 0 \\
\hline Shannon-Weiner Diversity & 1.60 & 1.09 & 1.33 & 0.63 & 1.07 & 0.84 & 0.13 & 0 & 0 & 0 \\
\hline
\end{tabular}

Table 3: Fish abundance and diversity in Ivo River Basin.

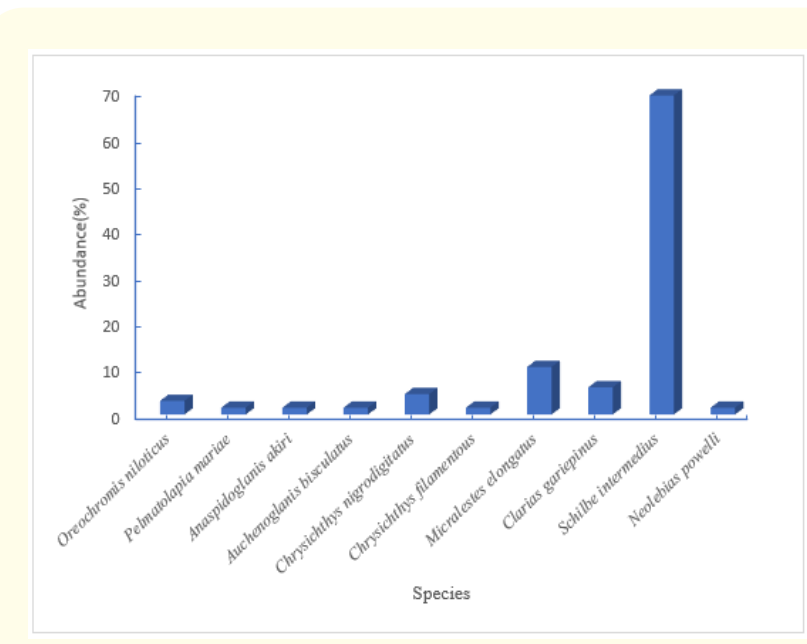

Figure 1: Relative abundance of fish species in Ivo River Basin.

\section{Conclusion}

The abundance and diversity of fish fauna in the Ivo River Basin was low and this is reflected in the food chain viz a viz feeding relationships, these intrinsic factors with the recently established extrinsic pollution stress as well as the record of an endangered and critically endangered species showed that the river basin was perturbed. The fish fauna in Ivo River Basin was under perturbation especially with a low forager abundance which were outnumbered by carnivorous species. This showed that the foragers were more sensitive to previous reported pollution stress and as such they could not survive nor sustain the food chain in the river ba- sin. There is an urgent need to restore the population balance of the fish fauna by reducing the disturbances from extrinsic sources and introducing more prolific foragers like the cichlidae in the river basin.

\section{Bibliography}

1. Ugwumba A O and Ugwumba A A A. "Poverty alleviation through aquaculture" In poverty alleviation for Biodiversity Management (Eds Ivbijahro M. F. A) Book builders edition Africa, Ibadan (2013): 431.

2. Taiwo Y F. "Fish diversity in two reservoirs in southwest Nigeria". Proceedings of fisheries society of Nigeria (FISON) ASCON, Badagry 25th-29th October (2010): 258-265.

3. Januchowski-Hartley SR., et al. "Fresh Waters and Fish Diversity: Distribution, Protection and Disturbance in Tropical Australia". PLoS ONE 6.10 (2011): e25846.

4. Vorosmarty C J., et al. "Global threats to human water security and river biodiversity". Nature 468 (2010): 334-334.

5. Ogueri C., et al. "Assessment of heavy metals in fish species and some physico-chemical parameters of Oguta lake, Oguta, Imo state, Nigeria". International Journal of Hydrology (2018).

6. Wang L., et al. "Effects Of Dams In River Networks On Fish Assemblages In Non-Impoundment Sections Of Rivers In Michigan And Wisconsin, USA". River Resources Application 27 (2011): 473-487. 
7. Dan-kishiya A S., et al. "Ichthyofauna composition and Diversity of a Tropical Water Supply Reservior: A case Study of Lower Usuma Reservior in Bwari, Abuja, Nigeria". American Journal of Research Communication 1.9 (2013): 188-203.

8. Ipinmoroti M O. "Ichthyofauna diversity of Lake Asejire: Ecological implications". International Journal of Fisheries and Aquaculture 5.10 (2013): 248-252.

9. Abdul W O., et al. "Food And Feeding Habits of Some Fish Species in Ogun State Coastal Estuary, Ogun State, Nigeria”. Journal of Agricultural Science and Environment 16.1 (2016): 6174.

10. Yem IY., et al. "Food habit of the catfish Chrysichthys nigrodigitatus (Geoffrey Saint Hilaire, 1808) in Kainji Lake, Nigeria". Nature and Science 7 (2009): 17-22.

11. Ezekwe I C. "Impact of Mining on in the Ishiagu Area of Southeastern Nigeria". A PhD Thesis submitted to the Department of Geography and Planning, Abia State University, Uturu, Nigeria (2009).

12. Aroh K N., et al. "Physico-chemical properties of pit-water from ishiagu lead/ zinc mine as an index for alkaline classification of the mine drainage". Journal of Applied Science and Environmental Management 11.4 (2007): 19-24.

13. Ezekwe C I., et al. "Metal Loadings and Alkaline Mine Drainage from Active and Abandoned Mines in the Ivo River Basin Area of Southeastern Nigeria". Mine Water Environment 32 (2013): 97-107.

14. Oyediran A G., et al. "Seasonality, Abundance and Distribution of Macro-benthic invertebrates as bio-indicators of Water quality in Ikwo River, Ishiagu, South-Eastern Nigeria". Journal of Faunal and Biological Sciences 4.2 (2017): 43-46.

15. Asiegbu V O., et al. "Preliminary investigation of the Distribution and relative abundance of plankton and fish species in Ivo River Basin Southeastern Nigeria". Acta Scientific Microbiology Journal 2.4 (2019): 8-15.

16. Francis A and Sikok F. "Fish Families of Oguta Lake Southeastern Nigeria, And Sustainable issues”. Journal of Natural Science Research 4.9 (2014): 39-43.

17. Swingle HS. "Relationships and dynamics of balanced and unbalanced fish populations". Alabama Polytechnic Institute, Agric. Exp. Stn. Bull. No. 274 (1950).
18. Adeyemi S 0., et al. "Food and feeding habits of Oreochromis niloticus in Lake Gbedikere, Bassa, Kogi State". Continental Journal of Animal and Veterinary Research 1 (2009): 25-30.

19. Muhammed H M., et al. "Biodiversity of fishes of Tagwai Reservoir, Minna, Niger State, Nigeria”. Cogent Biology 5.1 (2019): 1-9.

20. Jenyo A and Oladele A H. "Heavy Metals Assessment in water, sediments and selected aquatic organisms in Lake Asejire, Nigeria”. European Scientific Journal 12.24 (2016): 339-351.

21. Offem B O., et al. "Influence of Seasons on Water Quality, Abundance of Fish and Plankton Species of Ikwori Lake, SouthEastern Nigeria". Fisheries and Aquaculture Journal 13 (2011): 1-18.

22. Okogwu O I and Ugwumba O A. "The abundance and Diversity of the Fin and Shell Fish of Mid-Cross River, South-East, Nigeria". The Zoologist 8 (2011): 19-24.

23. Ayoade A., et al. "Diet and dietary habits of the fish Schilbe mystus (Siluriformes: Schilbeidae) in two artificial lakes in Southwestern Nigeria". Revista Biologica Tropica 56.4 (2008): 1847-1855.

24. Maneechan W and Prommi T O. "Diversity and Distribution of Aquatic Insects in Streams of the Mae Klong Watershed, Western Thailand". Psyche (2015).

25. Agostinho AA., et al. "Dams and the fish fauna of Neotroprical region: impacts and management related to diversity and fisheries". Brazilian Journal of Biology 68.4 (2008): 1119-1132.

26. Odo G E., et al. "The fish fauna of Anambra river basin, Nigeria: species abundance and morphometry". International Journal of Tropical Biology 57.1-2 (2009): 177-186.

27. Uche FO., et al. "Ichthyofauna diversity of Ivo River Ebonyi State Nigeria". Proceeding of the 51st Annual conference of the Agricultural Society of Nigeria Abuja (2017): 911-917.

\section{Volume 4 Issue 7 July 2021 \\ (C) All rights are reserved by EZEKWE Ifeanyichukwu Clinton., et al.}

